\title{
Imprisonment of Tax Non-Payers - an Abuse of Power or a Measure of Legal Discipline?
}

The goal of this paper is to share some remarks concerning the possibility of application of criminal measures in the case of tax non-payers. Of course in the field of taxation there existed many casuistic crimes of Roman criminal law which could be committed by tax collectors, such as illegal collections, imposing illegal or excessive taxes, theft of paid taxes etc. ${ }^{1}$ These resulted sometimes in severe punishments, not only of pecuniary character, but sometimes even in the death penalty. On the other hand, taxpayers could also violate the law, especially if they fraudulently evaded paying tax (crimen fraudati vectigalis) ${ }^{2}$. The usual consequence of such violation was confiscation of property, which was a penalty of administrative character imposed by tax collectors, but as it seems it was considered a criminal measure as well ${ }^{3}$. However, the question arises, whether in fact it was possible to apply a strictly criminal penalty in such cases, such as imprisonment ${ }^{4}$.

The source which provoked the whole issue to appear is the fragment of Res Gestae of Ammianus Marcellinus, who presents an interesting case concerning the rules of Valentinian:

1 Codex Iustinianus, X, 20, 1; XII, 57, 1 ed. P. KRUEger, [in:] Corpus Iuris Civilis, vol. II, Berolini 1954 (cetera: CJ); Digesta XLVIII, 6, 12, rec. T. Mommsen, [in:] Corpus Iuris Civilis, vol. I, Berolini 1906 (cetera: Dig.); XLVIII, 14, 1, 3 (imposing new illegal taxes); CJ, VI, 2, 8 (delict of theft of tax collected).

2 This term appears only once in the legal sources (Dig., XXXIX, 4, 8). See A. Berger, Encyclopedic Dictionary of Roman Law, Philadelphia 1953 (s.v. crimen fraudati vectigalis). The Romans were probably as creative in this matter, as contemporary taxpayers, which may be concluded from the following text concerning cutting vines, removing buds from fruit trees and pretending to be poor in order to evade paying tax: Quisquis vitem succiderit aut feracium ramorum fetus hebetaverit, quo declinet fidem censuum et mentiatur callide paupertatis ingenium, mox detectus competenti indignationi subiciatur. Illo videlicet evitante calumniam, qui forte detegitur laborasse pro copia ac reparandis agrorum fetibus, non sterilitatem aut inopiam procurasse (CJ, XI, 58, 2).

3 Some sources clearly refer to confiscation as a penalty for committing fiscal crimes, e.g. Dig. XXXIX, 4, 8 and 4, 14. Thus it may have a dual character. It seems reasonable to distinguish the above - mentioned autonomous penalty from confiscation as a criminal measure used in certain cases of condemnation (publicatio bonorum), cf. T. Mommsen, Römisches Strafrecht, Leipzig 1899, p. 1005.

4 Contemporary Polish law provides such possibility, but the matter could present itself differently in Ancient Rome, see Penal Fiscal Code, especially Title 6 and article 57. 
Denique tributorum onera vectigaliumque augmenta multiplicata, optimatum quosdam ultimorum metu exagitatos mutare conpulerunt sedes, et flagitantium ministrorum amaritudine quidam expressi, cum non suppeteret quod daretur, erant perpetui carcerum inquilini: e quibus aliquos, cum vitae iam taederet et lucis, suspendiorum exoptata remedia consumpserunt ${ }^{5}$.

Circa 375 A.D. Probus reached the Praetorian Prefecture and started to introduce an entirely strict tax policy, causing many citizens to escape. Furthermore however, he incarcerated some of them, so they became constant inhabitants of the prison; a few most desperate prisoners committed suicide. Concerning the previous remarks, what did Ammianus Marcellinus mean by carcer in this context? Was it a penalty, a criminal preventive measure or merely a means to force resistant tax payers to meet their commitments? And first and foremost, was it a legal act or an abuse of power?

The intuitive response suggests the latter, but it is not sufficient as an argument in scientific reflection. Of course one must refer to Roman jurists' texts and the legal status quo of that time. The answer to that matter may be found in the Codex Justinianus containing one of Constantine's constitutions, which seems to refer to this exact case.

Nemo carcerem plumbatarumque verbera aut pondera aliaque ab insolentia iudicium reperta supplicia in debitorum solutionibus vel a perversis vel ab iratis iudicibus expavescat. Carcer poenalium, carcer hominum noxiorum est: officialium et cum denotatione eorum iudicum, quorum de officio coercitiores esse debebunt, qui contra hanc legem admiserint. Securi iuxta praesidem transeant solutores: vel certe, si quis tam alienus ab humano sensu est, ut hac indulgentia ad contumaciam abutatur, contineatur aperta et libera et in usum hominum instituta custodia militari. Si in obdurata nequitia permanebit, ad res eius omnemque substantiam eius exactor accedat solutionis obsequio cum substantiae proprietate suscepto. Qua facultate praebita omnes fore credimus proniores ad solvenda ea, quae ad nostri usus exercitus pro communi salute poscuntur. ${ }^{6}$

5 Finally, the burden of tributes and the repeated increase in taxes compelled some of the most distinguished families, hounded by the fear of the worst, to leave the country; others, crushed by the severity of the dunning tax-collectors, having nothing to give, became permanent inmates of the prisons; and some of these, now weary of life and light, died by the noose as a welcome release - AMmianus MARCELLINUs, Rerum gestarum libri qui supersunt, XXX, 5, 6, trans. J. C. RolfE, vol. II, London-Cambridge Mass. 1940.

6 CJ, X, 19, 2, pr: Let no one apprehend being placed in prison, whipped with leaded scourges, tortured with weights, or subjected to any other punishment by perverse or angry judges, for having been delinquent in the payment of taxes. Imprisonment should only be inflicted upon those who are guilty, and judges and their subordinate officials should be aware of this fact, and if they violate this law shall be branded with infamy. Persons liable to the payment of taxes can, with safety to themselves, appear before the Governor; or, if anyone should be so destitute of human feeling as to abuse Our indulgence by being guilty of obstinacy, he shall be confined in a military prison which is open, healthy, and fitted for the occupation of men. If he should continue in his perverse wickedness, the collector shall seize all his property, and make payment of the taxes out of the same. We believe that by granting this power to collectors, all persons will be more inclined to the payment of those contributions which are demanded by the common welfare for the use of Our army. Cf. Codex Theodosianus, XI, 7, 3, ed. T. Mommsen, P.M. Meyer, [in:] Theodosiani libri XVI cum Constitutionibus Sirmondianis et leges novellae ad Theodosianum pertinentes, vol. I-II, Berolini 1954 (cetera: CTh). All translations of Corpus Iuris Civilis by S.P. ScotT, The Civil Law, Cincinnati 1932. 
The Emperor in his decision from 320 A.D. forbade judges to imprison, to whip with leaded scourges ${ }^{7}$, to torture with weights or to use any other punishment against tax non-payers. As he states, carcer poenalium, carcer hominum noxiorum est, which clearly suggests that they are not considered criminals, so they do not deserve this kind of treatment. The judges and their officials are to be branded with a kind of infamy (denotatio) $)^{8}$ if they act against his regulations. Tax debtors have the opportunity to appear before the governors to pay their debts, but if they still try to evade the liability, they may be kept in custodia militaris, which is open, healthy and created for the use by men. Tax collectors, however, may seize the property of those, who try not to meet their obligation notwithstanding. This regulation confirms the previously mentioned penalty of confiscation in the case of non-payment of the tax.

Constantine clearly introduced the illegality of imprisonment and other penalties for non-paying of taxes. In accordance with his words, prisons were only for guilty people, thus probably for serious criminals and not for tax debtors, even though they diminished the property of the State.

To comprehend such a decision it is essential to investigate his argumentation and underline the necessary distinctions. The Emperor introduced a kind of a gradual procedure of collecting overdue tax from citizens. Firstly, they had a chance to pay the debt to the governor without any negative consequences. But if they remained unwilling, they could be kept in military custody. Nevertheless, if they continued to evade paying the tax, tax collectors could seize their property and in this way satisfy the debt.

At this point one may assume that Probus illegally incarcerated tax debtors. There is, however, a doubt concerning the meaning of the word carcer and custodia in the texts mentioned. Both terms were sometimes used in the same meaning of 'prison', but Constantine makes a clear distinction between them - one is illegal and the other not. What makes them so different?

To answer these questions some necessary remarks have to be presented. Both carcer and custodia may be classified as preventive measures used in the Roman criminal procedure to secure the wrongdoer. The spectrum of such measures is very similar to the contemporary institutions of criminal law ${ }^{10}$, which is evident if one compares modern legal texts with the following fragment of Digestae.

Cf. P. KoџоDKo, Rzymska terminologia prawna stosowana na określenie narzędzi stosowanych podczas chtosty, ZP.UKSW, 6, 2006, p. 121-144; IDEM, Chłosta jako dodatkowy środek karny zaostrzajacy dolegliwość właściwej kary, [in:] Salus rei publicae suprema lex. Ochrona interesów państwa w prawie karnym starożytnej Grecji $i$ Rzymu, ed. A. DęBIŃski, H. Kowalski, M. KuRYŁowicz, Lublin 2007, p. 87-102.

8 A kind of infamy, because the term denotatio as a reprimand appears in legal sources only in this fragment, cf. J. Sondel, Słownik łacińsko-polski dla prawników i historyków, Kraków 1997 (s.v. denotatio). 9 Ibidem (s.v. carcer; custodia). Cf. also K. Amielańczy , Custodia, carcer, vincula publica. Pozbawienie wolności w rzymskim prawie karnym za panowania cesarza Hadriana, [in:] Wspótczesna romanistyka prawnicza, red. A. Dęвı́́ski, M. WójcıK, Lublin 2004, p. 11-24.

${ }_{10}$ Penal Code, Title 28, Preventive measures. See A. Lovato, Il carcere nel diritto penale romano dal Severi a Giustiniano, Bari 1994, p. 11-12. 
De custodia reorum proconsul aestimare solet, utrum in carcerem recipienda sit persona an militi tradenda vel fideiussoribus committenda vel etiam sibi. Hoc autem vel pro criminis quod obicitur qualitate vel propter honorem aut propter amplissimas facultates vel pro innocentia personae vel pro dignitate eius qui accusatur facere solet. ${ }^{11}$

Prison, military custody and personal security were conventionally used in Roman Law. However, the order of the presented institutions is not insignificant - they are enumerated from the most severe to the mildest measure. This is easy to understand if one considers the character and conditions of ancient prisons. Usually they were very small, dim, lacking both fresh air and food. The worst of all was probably the almost complete dependence on the discipline or mere moods of custodians ${ }^{12}$. On the other hand custodia militaris was a custody over the debtor in the magistrate's or even a private house. The detainee was guarded day and night, but he could move without restraint, meet his friends and family, live as usual ${ }^{13}$. Of course, different kinds of securities or guarantees were the most comfortable measure for the debtors. It is important to mention that all of them were not strict and separate institutions, but rather certain points on the continuum of preventive measures used in Roman Law ${ }^{14}$.

A similar distinction is also presented in the following text of Ulpian:

Divus pius ad epistulam antiochensium graece rescripsit non esse in vincula coiciendum eum, qui fideiussores dare paratus est, nisi si tam grave scelus admisisse eum constet, ut neque fideiussoribus neque militibus committi debeat, verum hanc ipsam carceris poenam ante supplicium sustinere $^{15}$.

${ }_{11}$ Dig., XLVIII, 3, 1: When accused persons are to be placed in custody, the Proconsul should determine whether they should be sent to prison, delivered to a soldier, or committed to the care of their sureties, or to that of themselves. This is usually done after taking into consideration the nature of the crime of which the defendant is accused, or his distinguished rank, or his great wealth, or his presumed innocence, or his reputation. Also Dig., II, 11, 4, 1: ed plane si vinculis vel custodia militari impeditus ideo non stetit...; XLVIII, 3, 2, pr.: lege publicorum cavetur, ut sistendum vel a domino vel ab extero satisdato promittatur: quod si non defendatur, in vincula publica coici iubetur...; I, 18, 14: et tamen diligentius custodiendus erit ac, si putabis, etiam vinculo coercendus... ut a suis vel etiam in propria villa custodiatur...

12 J.-U. Krause, Gefängnisse im Römischen Reich, Stuttgart 1996, p. 271-304. Beside numerous literary sources, one can conclude the conditions in prison also on the basis of legal sources, e.g. CJ, I, 4, 9 pr.; IX, 4, 1; IX, 47, 23 pr. Cf. also W. LiтEwski, Rzymski proces karny, Kraków 2003, p. 89-90.

${ }_{13}$ E.g. Titus Livius, Ab Urbe condita, XXIV, 45, 8; The Acts of the Apostles, XXVIII, 16; Cassius Dio, Roman History, LVIII, 3, trans. E. CARY, H.B. Foster, vol. VII, Cambridge 1959 (cetera: Cassius Dio); Josephus Flavius, Jewish Antiquities, XVIII, 6, 7, trans. L.H. Feldman, vol. VIII, Cambridge 1965.

${ }_{14}$ There are examples which are hard to classify, especially between custody and surety, e.g. SuEtonIUs, De vita caesarum / The Lives of the Caesars, De vita Caesarum, VII, 2, 3, trans. J.C. RolfE, Cambridge 1960 (Gnaeus Piso kept in custody of his brother).

${ }_{15}$ Dig., XLVIII, 3, 3: The Divine Pius stated in a Rescript, in Greek, to the people of Antioch, that anyone who was ready to furnish sureties for his appearance should not be placed in prison, unless it was evident that he had committed so serious a crime that he should not be entrusted to the care of any sureties, or soldiers; but that he must undergo the penalty of imprisonment before suffering that for the crime of which he is guilty. 
Antoninus Pius ordered not to put in chains people prepared to furnish sureties, unless their crime was so serious that neither sureties nor military custody would be sufficient. Such criminals were committed to prison to suffer the penalty of imprisonment before the proper punishment. It is evident however, that carcer was perceived substantially differently from the rest of the preventive measures and constituted a kind of informal penalty because of its character. Ulpian clearly expressed such attitude in the above mentioned fragment. This might be the reason why Constantine forbade its application, but simultaneously considered custodia militaris appropriate even for public debtors. As it is stated in the previously analyzed fragment, the application of a certain measure was dependent on the nature of the crime committed, the status of the criminal and his guilt. Not paying taxes was not perceived as such a violation of law to be punished by so cruel treatment ${ }^{16}$.

So again, most likely Probus abused his power in order to collect delinquent taxes. The more so because, as it is expressly written in Ammianus' account, he incarcerated noble men (optimati) and some of them committed suicide. In Roman criminal law, there existed a very distinctive classification of perpetrators based on the social status - honestiores and humiliores. The former were treated in a much more privileged manner, so it was illegal to apply certain measures against them ${ }^{17}$. Even if imprisonment was a part of legal proceedings, it would be most unlikely to commit to prison representatives of a noble social class ${ }^{18}$.

Of course, Probus could have used other preventive measures, including military custody or all kinds of securities. Constantine affirmed such a possibility expressis verbis in the next constitution from 335 A.D., concerning the same matter.

Provinciales pro debitis plumbi verbera vel custodiam carceris minime sustinere oportet, cum hos cruciatus non insontibus, sed noxiis constitutos esse noscatur, satis vero sit debitorem ad solvendi necessitatem capione pignorum conveniri ${ }^{19}$.

${ }^{16}$ However, it seems that it was considered a serious crime. It was one of three crimes, which enabled torturing the slaves of a master who committed a crime, $C J$, IX, 41, 1 pr.

17 T. Mommsen, op. cit., p. 1030; G. Cardascia, Lapparition dans le droit des classes d'honestiores et d'humiliores, RHDFE 27, 1950, p. 305-337 and 461-485; P. GARNSEY, Social status and legal privilege in the Roman Empire, Oxford 1970, p. 103; R. RILINGER, Humiliores-honestiores. Zu einer sozialen Dichotomie im Strafrecht der römischen Kaiserzeit, München 1988; M. BALZARINI, Nuove prospettive sulla dicotomia honestiores-humiliores, [in:] Idee vecchie e nuove sul diritto criminale, a cura di A. BuRdESE, Padova 1988, p. 159; A. Lovato, op. cit., p. 14-16; K. AmielańCZyK, Rzymskie prawo karne w reskryptach cesarza Hadriana, Lublin 2006, p. 234.

${ }_{18}$ Although it is only an assumption, there are sources mentioning the incarceration of a decurion: Dig., XXVIII, 3, 6, 7; XLIX, 4, 1.

${ }_{19}$ CTh, XI, 7, 7. The provincials must not suffer lashes of leaded whips or the custody of prison on account of unpaid taxes due, since it is recognized that such tortures have not been established for the innocent, but for the guilty. It shall suffice for a delinquent taxpayer to be summoned to the necessity of payment by the seizure of pledges (trans. C. Pharr, The Theodosian Code and Novels and the Sirmondian Constitutions: A Translation with Commentary, Glossary, and Bibliography, Princeton 1952). 
He repeated the previous regulation concerning the illegality of imprisonment and whipping of tax debtors, but simultaneously he mentioned that a pledge was sufficient in the case of tax liability. This repetition may be caused by continuous breaching of the previous law, probably happening mostly in the provinces, which may be concluded first of all from the addressee of this constitution, praeses Sardiniae and provinciales ${ }^{20}$.

To conclude, such a case seems to be presented by Ammianus Marcellinus in his work - an illegal act of abusing the Praetorian competence. But was the carcer used by Probus as a penalty, preventive measure or informal means of constraint? Actually, the problem is definitely much more extensive and concerns the problem of the existence of the penalty of imprisonment in Roman criminal law, which is far beyond the scope of this analysis ${ }^{21}$. The reflection is limited only to the most certain point in this discussion that incarceration as a punishment was at least for some time and for certain groups of perpetrators forbidden in Ancient Rome. Nevertheless, it was used commonly by governors of provinces. One of the libri terribiles of the Digestae provides Ulpian's opinion on the matter:

Solent praesides in carcere continendos damnare aut ut in vinculis contineantur: sed id eos facere non oportet. Nam huiusmodi poenae interdictae sunt: carcer enim ad continendos homines, non ad puniendos haberi debet ${ }^{22}$.

The jurist comments that governors tend to punish the condemned with prison or chains, but such practices are illegal, because prison should be used for detaining people, not for punishing them. It seems that this fragment may refer to the issue under analysis, it excludes the possibility of Probus' using the prison as a punishment, at least in accordance with the law. On the other hand, there existed no criminal procedure in the case of non-paying of tax none is known until today. Thus, it is impossible to use the term penalty in its context concerning penal law. In the light of the analyzed sources, it is obvious that Probus illegally used prison to force the unfortunate taxpayers to meet their obligation. In Ancient Rome there existed a common, but obviously illegal practice of using certain preventive measures, such as prisons or tortures, to achieve some goals and enforce obedience. So in general it is not a very discussed academic matter whether or not there existed prison as a penalty in Roman Law; the question is, how it was used in daily life. As it seems, people were kept illegally in prisons, in very different situations, for the purpose of being forced them to perform expected acts ${ }^{23}$.

\footnotetext{
${ }^{20}$ Many examples of imprisonment of tax non-payers were also found in Egypt, see S.F. TovAR, Violence in the Process of Arrest and Imprisonment in Late Antique Egypt, [in:] Violence in Late Antiquity: Perceptions and Practices, ed. H.A. DraKe, Aldershot-Burlington 2006, p. 103-112, esp. 105.

${ }^{21}$ Cf. A. Lovato, op. cit., p. 77-170.

22 Dig., XLVIII, 19, 8, 9: Governors usually sentence criminals to be confined in prison, or to be kept in chains; but they should not do this, for penalties of this kind are forbidden, as a prison should be used for the safe-keeping of men, and not for their punishment.

${ }^{23}$ A. Lovato, op. cit., p. 25-36, 77-109 and 212-219.
} 
There also exists copious historical evidence proving such a tendency in the daily practice of justice. The most characteristic, is the behavior of Tiberius, presented by Cassius Dio in his History of Rome ${ }^{24}$. The Emperor willingly delayed his return to the city, so that the prisoner could suffer as long as possible both from the loss of his civic rights and from terror. They all show that prison was commonly used as an informal penalty not only for criminals, before or even without any procedure undertaken afterwards. It achieved such an extent that imperial constitutions had to be issued. Nonetheless, such practice still existed, mostly in the provinces, as described by Ammianus Marcellinus. As it appears, there was no criminal responsibility of tax non-payers in Roman criminal law, but some criminal measures were used as a manifestation of abuse of authority.

\begin{abstract}
In the field of taxation there existed many casuistic crimes of Roman criminal law, committed both by tax payers and tax collectors, but non-payment of taxes was not one of them. As a rule taxpayers risked confiscation of property by avoiding the fulfillment of their obligation. There exists some historical evidence, however, which suggests the possibility of imprisonment of taxpayers. Was it possible to inflict criminal punishments in such cases? Legal texts give some reflections to the contrary- Roman emperors prohibited the use of imprisonment in non-criminal matters. The number of these prohibitions indicates, that there were many situations of this kind. It seems that especially in the provinces the governors abused their power and used illegal measures, such as tortures, whipping and imprisonment, to force citizens to pay taxes.
\end{abstract}

\author{
Przemysław Kubiak \\ Katedra Prawa Rzymskiego \\ Wydział Prawa i Administracji \\ Uniwersytet Łódzki \\ ul. S. Kopcińskiego 8/12 \\ 90-232 Łódź, Polska \\ cubiacus@poczta.onet.pl
}

\footnotetext{
${ }^{24}$ Cassius Dio, LVIII, 3: Yet Tiberius, after acting in this manner, did not permit his victim to die, in spite of the other's desire for death as soon as he learned of the decree. Instead, in order to make his lot as cruel as possible, he bade Gallus be of good cheer and instructed the senate that he should be guarded without bonds until he himself should reach the city; his object, as I said, was to make the prisoner suffer as long as possible both from the loss of his civic rights and from terror. And so it came to pass; for he was kept under the eyes of the consuls of each year, except when Tiberius held the office, in which case he was guarded by the praetors; and this was done, not to prevent his escape, but to prevent his death. He had no companion or servant with him, spoke to no one, and saw no one, except when he was compelled to take food. And the food was of such quality and amount as neither to afford him any satisfaction or strength nor yet to allow him to die (trans. E. CARY).
} 